\title{
An Analysis of Cash Flow Report Effect on Financial Performance (Case Study in Course and Training Institutions Putra Perwira Sukoharjo 2014-2016)
}

\author{
Sri Supatminingsih, Setyawati \\ STIE AAS Surakarta, Central Java, Indonesia \\ patminingsihsri36@gmail.com
}

\begin{abstract}
The purpose of this study is 1) To determine the effect of cash flow of operating activities partially to the financial performance at the Institute Course and Training Son Sukoharjo officers. 2) To know the effect of cash flow from investment activity partially to financial performance at Training Institute Institute and Training of Officer Sukoharjo. 3) To know the effect of cash flow from financing activities partially to financial performance at Training Institute Institute and Training of Officer Sukoharjo. 4) To determine the effect of cash flows from operating activities, cash flows from investment activities and cash flows from simultaneous financing activities to financial performance at the Course Institute and Training of Officers of Sukoharjo Officers. 5) To find out how much the cash flow effect of operating activities, the flow Cash from investment activities and cash flows from simultaneous financing activities to financial performance at the Sukoharjo Personnel Training Course and Training Institute. The object of this research is the institute's financial report and the training of sukoharjo officer's son. The sample in this study using financial report data while the period of data used in this study from monthly data from 2014 until 2016. Based on the results note that the operating variables have a partial significant influence on financial performance. This is evidenced by the value of $t_{\text {count }}(0.176)$ greater than $t_{\text {table }}(0.00075)$ or can be seen from the significance value of $0.045 \leq 0.05$. The investment variable has a significant influence on financial performance. This is evidenced by the investment variable $t_{\text {count }}(0.103)$ greater than $t_{\text {table }}(0.00075)$ or can be seen from the significance value of $0.026 \leq$ 0.05. The funding variable has no significant partial effect on financial performance. This is evidenced by the financing variables $t_{\text {count }}(0.003)$ is smaller than $t_{\text {table }}(0.00075)$ or can be seen from the significance value $0.172 \geq 0.05$.
\end{abstract}

Keywords: cash flow, financial performance

\section{Introduction}

Financial reporting is a financial statement that is supplemented by other related information, either directly or indirectly with information provided by the financial accounting system, such as information on company resources, earnings, current costs, information about the prospect of the company which is an integral part with aim to meet a sufficient level of disclosure (Hanafi, 2007: 63). As it is known that the field of finance is a very important field in a Course Institute and Training of Officer Son. Both large-scale and small, or is a motive or non-profit motive motives. The development of the business world is getting more advanced, resulting in competition between the Course and Training Institution is getting tighter, thus 
demanding the Course and Training institution to be more efficient in operation can continuously improve its competitiveness for the sake of the company's survival. Statements of cash flows within an enterprise are presented to provide cash information such as management, creditors, and investors in particular regarding the cash of the Institute for Course and Training of Officer Personnel for a certain period. Statements of cash flows as an integral part of the financial statements which provide data on the cash conditions of the Course Institute and Training of Officer Personnel from operating, investing and financing activities.

Currently Course and training institutions are required to prepare financial statements consisting of statements of financial position, income statement, statement of changes in equity and cash flow statement. Statements of cash flows shall be required to be made by each company from January 1, 1995, in accordance with PSAK no. 2 the purpose of a cash flow statement is to describe the cash receipts and uses for operating activities and cash-related activities for a period. Each company is required to include a cash flow statement but as stated in the Indonesian Accounting Principles (PAI) that the company is free to choose to prepare a statement of financial position or cash flow statement, before it is finally made sure by PSAK no. 2, as a result many companies do not include cash flow statement in their financial statements. The benefits of making cash flow statements are still poorly realized by users of financial statements. Until now, users of financial statements rely solely on the income statement and the statement of financial position as a measure of decisionmaking performance of the Course Institute and Training of Officers Personnel in generating profits, regardless of the ability of the Course and Training Institute to generate net cash flow. The analysis of the cash flow statement is still not getting the attention, whereas cash is an important source needed for the operations of the company. So, by adding a cash flow statement for analysis will get additional information on the financial performance of the Course Institute and Training of Officer Putra Perwira, Furthermore can be one of the information for decision making to be taken.

Institute for Course and Training of Putra Perwira Sukoharjo as the object of research because to see how big the influence of operating cash flow, investment activity, and funding activity to financial performance for business development, hence the title "An Analysis Of Cash Flow Report Effect On Financial Performance (Study Case On Courses Institute And Training Putra Perwira Sukoharjo)".

\section{Literatures Review}

The media that can be used to assess the financial performance of the Course and Training Institute is the financial statements, and can assist the users of financial statements in assessing performance in making the right decision. One way to measure the performance level of the Course Institute and the training of Officer Personnel by using a cash flow statement in addition to the statement of financial position and income statement. The cash flow statement can provide information on changes in net assets, financial structure and the ability to influence the amount and timing of cash flows within face circumstances and opportunities. In addition cash flows can also provide information about the company's ability to generate cash (Soemarsono, 2005: 380). One of the analysis of financial performance by using cash flow statement is cash flow statement ratio. Cash flow statement analysis, the components of the statement of financial position and income statement as a ratio analysis tool. 
Financial performance is a description of the financial condition of a company that is analyzed by means of financial analysis, so it can be known about either the poor financial condition of a company that reflects the performance of work within a certain period. It is very important that resources are used optimally in the face of environmental change. Assessment of financial performance is one way that can be done by the management in order to fulfill its obligations to the funders and can achieve the goals set by the Course Institute and Training of Officer Putra Perwira.

Analysis of a company's financial statements is basically done to determine the level of profitability (profit) and the level of risk or the level of a company's health. The easiest work in financial analysis of course calculates the financial ratios of a company. (Hanafi and Halim, 2005: 12).

\section{Research Method}

This research is to know the effect of cash flow of partial operational activity to financial performance at Institute of Course and Training of Putra Perwira Sukoharjo, to know the effect of cash flow from partial investment activity to financial performance at Institute of Course and Training of Putra Perwira Sukoharj to know current influence cash from partial funding activities on financial performance at the Sukoharjo Personnel Course and Training Institute, to determine the effect of cash flows from operating activities, cash flows from investment activities and cash flows from simultaneous financing activities to financial performance at the Institute of Course and Training of Officers Sukoharjo.5) To find out how much cash flow influence from operating activities, cash flow from investment activity and cash flow from financing activities simultaneously to financial performance at
Sukoharjo Officers' Training Course and Training Institute. The object of this research is the financial report of Training Institute and Training of Officer of Sukoharjo Officer. The sample in this study using financial report data while the period of data used in this study from monthly data from 2014 until 2016.

\subsection{Object of the Research}

The object of this research is the financial report of Training Institute and Training of Officer of Sukoharjo Officer. The data period used in this study is monthly data from 2014 to 2016.

\subsection{Research Data}

To process the data that has been collected from the results of research, it used the method of cash ratio statement analysis which consisting of:

1. Cash Flow Liquidity Ratio

a. Operating Cash Flow Ratio (AKO)

Operating Cash Flow Ratio =

Amount of Cash Flow Operation

Current Liabilities

b. Investment Activity Ratio

Cash flow

Investment Activity Ratio = ----------
Fixed assets

c. Cash Flows from Financing Activities

Ratio Interest Coverage $=$

Net Income + Cost of Interest + Income Tax

Interest Cost

\subsection{Data Analysis Method}

\section{a. Normality Test}

This test aims to test whether in the regression model the dependent variable and independent variables have a normal distribution or not, the residual value has a normal distribution or not. A good regression model is to have a normal or near-normal residual value. If the distribution is normal then the line 
representing the real data will follow its diagonal line.

Normality test used in this study is Kolmogorov Smirnov with the criteria if the significance kolmogorov smirrnov $<5 \%$ then the data is not normal, on the contrary if kolmogorov smirnov significance $>5 \%$ then the normal data.

\section{b. Multicollinearity Test}

This test aims to test whether in the regression model found a correlation between independent variables. Good regression model should not occur correlation between independent variables. The tolerance value and the opposite (2) if the tolerance value $>0.10$ and Variance Inflation Factor (VIF) $<10$ does not occur Multicollinearity.

Another way to detect multicollinearity is to look at coefficients between independent variables. Regression model is said not to experience multicollinearity when the correlation between independent variables is weak.

\section{c. Heteroscedasticity Test}

To determine whether in the regression model there are variant and residual inequalities from one observation to another. To test whether or not heteroskedastisitas in this study used Glejser test, that is by regretting the residual absolute value of the independent variable. The presence or absence of heteroscedasticity is known by looking at its significance to a $5 \%$ degree of confidence. If the significance value> 0.05 then no heteroskedastisitas and if the value of significance> 0.05 then occurs heteroskedastisitas (Ghozali, 2011).

\section{d. Autocorrelation Test}

The autocorrelation test aims to test whether in linear regression model there is a correlation between the confounding error in the period $\mathrm{t}$ with the intruder error in period $t-1$ (previous). If there is a correlation, then there is called an autocorrelation problem. Autocorrelation arises because consecutive observations over time are related to each other. In the cross section data (autobiographical problems) the problem of autocorrelation is relatively rare because the "disturbance" on different observations comes from individuals, different groups. A good regression model is a regression independent of autocorrelation. Durbin Watson test in this study to see whether or not autocorrelation of the researchers.

Table 1. Durbin Watson

\begin{tabular}{lll}
\hline The null hypothesis & Decision & If \\
\hline $\begin{array}{l}\text { There is no positive } \\
\text { autocorrelation }\end{array}$ & Decline & $0<\mathrm{d}<\mathrm{dl}$ \\
$\begin{array}{l}\text { There is no positive } \\
\text { autocorrelation }\end{array}$ & $\mathrm{dl} \leq \mathrm{d} \leq \mathrm{du}$ \\
& desicison & \\
$\begin{array}{l}\text { There is no negative } \\
\text { autocorrelation }\end{array}$ & Decline & $\mathrm{d}-\mathrm{dl}<\mathrm{d}<4$ \\
$\begin{array}{l}\text { There is no negative } \\
\text { autocorrelation }\end{array}$ & No decision & $\mathrm{d}-\mathrm{du} \leq \mathrm{d} \leq 4-\mathrm{dl}$ \\
$\begin{array}{l}\text { Tdk ada autokorelasi, } \\
\text { positif atau negative }\end{array}$ & Tdk ditolak & $\mathrm{du}<\mathrm{d}<4-\mathrm{du}$ \\
\end{tabular}

\section{e. Multiple linear regression}

Multiple regression analysis is used to determine the effect of independent variables (cash flow from operating activities, cash flow from investment activity and cash flow from financing activities) to the dependent variable (financial performance of case study in the institution of course and training of sukoharjo officer's son) together and partially. In this research the multiple regression equation is:

$\mathrm{Y}=\mathrm{a}+\mathrm{b}_{1} \mathrm{X}_{1}+\mathrm{b}_{2} \mathrm{X}_{2}+\mathrm{b}_{3} \mathrm{X}_{3}+\mathrm{b}_{4} \mathrm{X}_{4}+\mathrm{b}_{5} \mathrm{X}_{5}+\mathrm{e}$ Whereas:

$\mathrm{Y}=$ Variable financial performance

$\mathrm{X}_{1}=$ Variable cash flows from operating activities 


$\mathrm{X}_{2}=$ Variable cash flows from
investment activity
$\mathrm{X}_{3}=$ Variable cash flows from
financing activities
$\alpha \quad=$ Constants
$\beta 1-3=$ Regression Coefficient
$\mathrm{e} \quad$ : error term

\section{f. Hypothesis testing (Test $t$ )}

This $t$ test is used to test the effect of each independent variable (cash flow from operating activities, cash flow from investment activity and cash flow from financing activities) to the dependent variable (financial performance). The steps used are as follows:

1) Determine the composition of the hypothesis

Ho: $\beta 1=0$, there is no significant effect between cash flow from operating activities, cash flow from investment activity and cash flow from funding activity to dependent variable (financial performance) together.

Ha: $\beta 1=0$, there is a significant influence between cash flow from operating activities, cash flow from investment activity and cash flow from financing activities to dependent variable (financial performance) together.

2) Determining the significant level $\alpha=$ $5 \%$

To know the acceptance or rejection of Ho, then the result of calculation of significance (sig value) compared with level of significant 0,05 . If the value of $\operatorname{sig}<0.05$ then Ho is rejected, which means there is a significant influence of independent variables on the dependent variable and vice versa if the value of sig $>0.05$ means there is no significant influence independent variable to the dependent variable. Another way of knowing acceptance or rejection of $\mathrm{Ho}$, is to compare between $\mathrm{t}$ arithmetic with $\mathrm{t}$ table. If $\mathrm{t}$ arithmetic $>\mathrm{t}$ table then Ho is rejected which means there is a significant influence on the independent variable to the dependent variable and vice versa if $\mathrm{t}$ arithmetic $<\mathrm{t}$ table which means there is no significant effect of independent variable to the dependent variable.

\section{g. Simultaneous Significant Test (F Test)}

The statistical test $\mathrm{F}$ aims to examine the effects of all independent or independent variables (cash flow from operating activities, cash flows from investment activities and cash flows from financing activities) collectively to the dependent or dependent variable (financial performance). This test is done with SPSS 17 program. The test steps are:

1) Determine the composition of the hypothesis

Ho: $\beta_{1}=\beta_{2}=\beta_{3}=\beta_{4}=\beta_{5}=0$, there is no significant effect of cash flow from operating activities, cash flows from investment activity and cash flows from financing activities to financial performance collectively.

Ho: $\beta_{1} \neq \beta_{2} \neq \beta_{3} \neq \beta_{4} \neq \beta_{5} \neq 0$, there is a significant effect of cash flow from operating activities, cash flow from investment activity and cash flow from financing activities to financial performance collectively.

2) Determine the level of significance $\alpha$ $=5 \%$

To know the acceptance or rejection of Ho, then the result of calculation of significance (sig value) compared with level of significant 0,05 . If the value of $\mathrm{sig}<0.05$, then $\mathrm{Ho}$ is rejected, which means there is a significant influence of independent variables on the dependent variable and vice versa if the sig value $>0.05$, means there is no significant effect of independent variables on the dependent variable. Another way of knowing accept or rejected by Ho is to 
compare between $\mathrm{F}$ arithmetic with $\mathrm{F}$ table. If $\mathrm{F}$ arithmetic $>\mathrm{F}$ table then Ho is rejected which means there is a significant influence of independent variables together to the dependent variable and vice versa if $\mathrm{F}$ arithmetic $<\mathrm{F}$ table then Ho accepted which means there is influence not significant independent variable together to variable dependent.

3) Coefficient of Determination $\left(R^{2}\right)$

This test is conducted to find out how much influence independent variables (cash flow from operating activities, cash flow from investment activities and cash flow from financing activities) to the dependent variable (financial performance).

The coefficient of determination is between 0 and 1 . The small value of $R^{2}$ means that the ability of the independent variable is very limited. $R^{2}$ is said to be good if it is closer to 1 . If $\mathrm{R} 2$ equals 1 it means that the independent variable has a perfect effect on the dependent variable. Whereas if $\mathrm{R}^{2}$ equals 0 , then there is no influence of independent variable to the dependent variable.

\section{Hypothesis Testing Results}

\section{a. Results of Research Variables}

In this research the sample used is 36 samples, based on financial data of Institut Putra Perwira sukoharjo for 3 years period 2014 until 2016. Multiple linear regression analysis result with the help of computer application program Package For Social Sience (SPSS) 16.0 For windows, then obtained results like this brought.
Tabel 2. Descriptive Statistics Descriptive Statistics

\begin{tabular}{llllll}
\hline & $\mathrm{N}$ & Minim & Max & Mean & Std. Deviation \\
\hline AKO & 36 & 2.411 & 27.869 & 8.2139 & 4.367243 \\
& & & & 7 & \\
AKI & 36 & .001 & .007 & .00300 & .001352 \\
AKP & 36 & 19.028 & 178.322 & 5.6014 & 27.357909 \\
Kinerja & 36 & .007 & .058 & .01758 & .013483 \\
$\begin{array}{l}\text { Valid N } \\
\text { (listwise) }\end{array}$ & & & & & \\
\hline
\end{tabular}

Source: Data processed, 2017

From the table above variable operating cash flow (X1) with the amount of data (N) of 36, showing average (mean) of $8.21397 \%$ with standard deviation of 4.367243. Operating cash flow the highest value of 27,869 and the lowest value 2,411. Investment cash flow variables (X2) based on table 4.1 with the amount of data $(\mathrm{N})$ of 36 , showing average (mean) of $0.00300 \%$ with a standard deviation of 0.01352 . The investment cash flow has the highest value of 0.07 and the lowest value is 0.01 . Funding cash flow variables (X3) based on table 4.1 with the amount of data $(\mathrm{N})$ of 36 , showing average (mean) of $5.6014 \%$ with standard deviation of 27.357909. The cash flow of funding has the highest value of 179,322 and the low of 19,028. Financial performance based on table 4.1 with total data $(\mathrm{N})$ of 36 , showing average (mean) of $0.01758 \%$ with standard deviation of 0.013483 . Financial performance has the highest value of 0.058 and the lowest value is 0.007 .

\section{b. Normality Test Results}

Normality test in this study using Kolmogorov - Smirnov Test. Normality test results can be seen in the table below: 
International Journal of Economics, Business and Accounting Research (IJEBAR)

Peer Reviewed - International Journal

Vol-2, Issue-1, 2018 (IJEBAR)

ISSN: 2454-1362, https://jurnal.stie-aas.ac.id/index.php/IJEBAR

Table 3. Normality Test Results

\begin{tabular}{llll}
\hline Variable & $\begin{array}{l}\text { Kolmogorov } \\
\text { Smirrov }\end{array}$ & $p$-value & Infromation \\
\hline $\begin{array}{l}\text { Unstandar } \\
\text { dized }\end{array}$ & 0,510 & 1,850 & $\begin{array}{l}\text { Distribution } \\
\text { of normal data }\end{array}$ \\
Residual & & & \\
\hline
\end{tabular}

Source: Data processed, 2017

From the results of Kolmogorov Smirnov test it showed that the significance value for regression model is greater than 0.05 . This shows that the regression equation for the model in this study has a normal distribution of data.

\section{c. Multicollinearity Test Results}

Table 4. Multicollinearity Test Results

\begin{tabular}{|c|c|c|c|}
\hline Variable & Tolerance & VIF & Information \\
\hline Investment & 0,110 & 0,941 & $\begin{array}{l}\text { There is no } \\
\text { multicollinearity }\end{array}$ \\
\hline Funding & 0,714 & 0,400 & $\begin{array}{l}\text { There is no } \\
\text { multicollinearity }\end{array}$ \\
\hline Operations & 0,122 & 0,897 & $\begin{array}{l}\text { There is no } \\
\text { multicollinearity }\end{array}$ \\
\hline
\end{tabular}

Source: Data processed, 2017

Based on Table 4.5 indicates that each variable has a VIF value below 10 and has a tolerance value above 0.10 . Thus it can be stated also this regression model there is no multicollinearity.

\section{d. Heteroscedasticity Test Results}

The result of heteroscedasticity test with regression model happened variance and residual inequality one observation to other observation. If the variance of one residual to another observation remains, it is called homoscedasticity and if different is called heteroscedasticity is shown in table 5 as follows:

Table 5. Heteroscedasticity Test Results

Variable Sig Information

Investment $\quad 0,666 \quad$ Heteroscedasticity does not occur

Funding $\quad 0,226 \quad$ Heteroscedasticity does not occur

Operations $0,704 \quad$ Heteroscedasticity does not occur

Source: Data processed, 2017
Based on the results shown in Table 4.3, using the glejser test it appears that all independent variables show the sig value greater than 0.05 , so it can be concluded that all these independent variables do not have problem of heteroscedasticity.

\section{e. Autocorrelation Test Results}

Autocorrelation test results using Durbin-Watson Test method. The autocorrelation test results as follows:

Table 6. Autocorrelation Test Results

$\begin{array}{lll}\begin{array}{l}\text { DW-count } \\ \text { value }\end{array} & \text { Criteria } & \text { Decision } \\ 1,888 & \mathrm{dU} \leq 1,888 \leq 4- & \begin{array}{l}\text { There is no positive } \\ \text { and negative } \\ \text { autocorrelation }\end{array}\end{array}$

Source: Data processed, 2017

Based on the table using the degree of error $(\alpha)=5 \%$, with $\mathrm{n}=36, \mathrm{k}=3$ then the upper limit (U) is 1.6539 while the lower limit (L) is 1.2953. Since the DW value of the regression result is 1.888 which means greater than the upper limit value and smaller than the upper limit value (U). Then the autocorrelation coefficient is greater than zero. Thus it can be concluded that the regression results are free from autocorrelation problems. In other words, the hypothesis that there is no autocorrelation problem is acceptable, whereas the null hypothesis that there is an autocorrelation can be rejected.

\section{f. Hypothesis Test Results}

This analysis is used to determine the effect of operations, investment and financing on financial performance partially and together. Results of data processing with the help of computer program SPSS version 17.0 obtained regression equation.

$\mathrm{Y}=0,002+0,002 \mathrm{X} 1-0,170 \mathrm{X} 2+$ 4,827X3

To interpret the results of the analysis, it can be explained: 
1) Constants of 0.002 with positive parameters indicate a positive and constant performance over operations, investments and financing.

2) The regression coefficient of the operation shows a positive coefficient of 0.002 thus it can be seen that the larger the operation will improve the financial performance and vice versa.

3) The regression coefficient of investment shows a negative coefficient of 0.170 so it can be seen that investment has a relationship in the opposite direction with financial performance. This means that if investment increases then financial performance will decrease and vice versa.

4) The coefficient of funding regression shows a positive coefficient of 4.827 so it can be seen that funding is greater then, it will improve finance and vice versa.

\section{g. Test Result t}

Based on the results of the analysis can be seen $t$ test results as shown in the following table:

Table 7. Test Results t

\begin{tabular}{lllll}
\hline Variable & $\mathrm{T}$ & $\mathrm{T}$ & Sig. & $\begin{array}{l}\text { Informatio } \\
\mathrm{n}\end{array}$ \\
& count & tabe & & \\
\hline Investme & 0.176 & 0.000 & 0,045 & $\mathrm{H}_{\mathrm{o}}$ rejected \\
$\mathrm{nt}$ & -0.103 & 75 & 0,026 & $\mathrm{H}_{\mathrm{o}}$ rejected \\
Funding & 0.003 & & 0,172 & $\mathrm{H}_{\mathrm{o}}$ rejected \\
Operation & & & & \\
$\mathrm{s}$ & & & & \\
\hline \multicolumn{1}{c}{ Source: }
\end{tabular}

Source: Data processed, 2017

From the results of table 4.5 can be seen t test results for operations, investment and financing of financial performance. The calculation is as follows:

1. Test the effect of operating variables on performance is as follows: Testing steps:

a. Determine the null hypothesis and the alternative hypothesis: $\mathrm{H}_{\mathrm{o}}: \beta_{1}=0$, meaning there is no significant influence between operations on financial performance. Ha: $\beta_{1} \neq 0$, meaning there is a significant influence between operations on financial performance.

b. Level of significant $(\alpha)=0,05$

$$
\begin{aligned}
& \mathrm{t}_{\text {table }}=(\alpha / 2, \mathrm{n}-\mathrm{k})=(0,05 / 2 ; 36-3) \\
& =(0,025 ; 33) \\
& =0,00075
\end{aligned}
$$

c. Testing Criteria

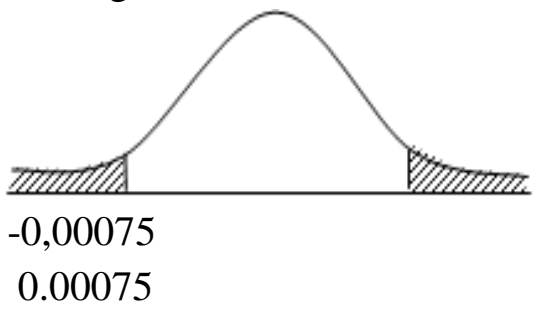

$\mathrm{H}_{\mathrm{o}}$ accepted $=-0,0075 \leq \mathrm{t} \leq 0,0075$

$\mathrm{H}_{\mathrm{o}}$ rejected $=\mathrm{t} \geq 0,0075$ or $\mathrm{t} \leq-0,0075$

d. Determine the value of $t_{\text {count }}$

From the results of data analysis that has been done by using computer assistance program SPSS for windows, it can be seen that $\mathrm{t}_{\text {count }}$ investment is equal to 0.103 .

e. $\mathrm{t}$ Investment test result and Discussion

Investment variable is known tcount value $(0,103)$ bigger than ttable $(0.00075)$ or can be seen from significance value $0,026<\alpha=0,05$. Therefore, Ho is rejected, meaning that investment has a significant influence on financial performance. The cash flows from the LKP Putra Perwira investment activity come from the cash flow of transactions that affect the investment of fixed assets and the acquisition of other investment instruments. Investing LKP Putra Perwira by purchasing fixed assets such as facilities and infrastructure Courses affect cash 
receipts and disbursements in relation to resources aimed at generating revenues and future cash flows.

\section{h. F Test Result}

This test is intended to test whether the regression model with the dependent variable and the independent variable has a statistical effect. F test results obtained results as follows:

$$
\begin{array}{cccc}
\multicolumn{4}{c}{\text { Table 8. F Test Results }} \\
\mathrm{F}_{\text {count }} & \mathrm{F}_{\text {tabble }} & \text { Sig } & \text { Information } \\
& & & \\
6,254 & 0,004 & 0,002 & \mathrm{H}_{\mathrm{o}} \text { rejected }
\end{array}
$$

Source: Data processed, 2017

Steps used:

1. Preparing nil hypothesis $\left(\mathrm{H}_{\mathrm{o}}\right)$ and alternative hypothesis $\left(\mathrm{H}_{\mathrm{a}}\right)$

$\mathrm{H}_{\mathrm{o}}: \beta_{1}=\beta_{2}=\beta_{3}=0$, there is no significant influence between operation, investment, and funding together to Financial performance $\mathrm{H}_{\mathrm{a}}: \beta_{1} \neq \beta_{2} \neq \beta_{3} \neq 0$, there is a significant influence between operation, investment, and cofinancing on Financial Performance.

2. Level of significant $(\alpha)=0,05$

$$
\begin{aligned}
\mathrm{F}_{\text {table }} & =0,05(\mathrm{k}-1 ; \mathrm{n}-\mathrm{k}) \\
& =0,05(4-1 ; 36-4) \\
& =0,05(3 ; 32) \\
& =0,004
\end{aligned}
$$

3. Testing Criteria

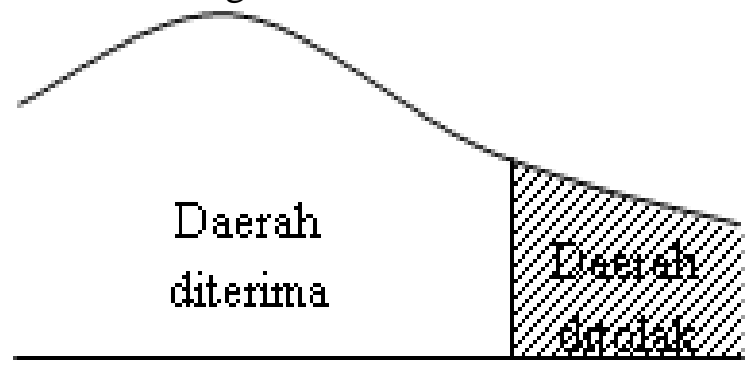

Whereas :

$$
\begin{array}{ll}
\mathrm{k} & =\text { Number of parameters } \\
\mathrm{n} & =\text { Number of Sample }
\end{array}
$$$$
\mathrm{H}_{\mathrm{o}} \text { accepted if } \mathrm{F} \text { count }<\mathrm{F} 0,05
$$

\section{$\mathrm{H}_{\mathrm{o}}$ rejected if $\mathrm{F}$ count $>\mathrm{F} 0,05$}

4. $F_{\text {count }}$ value

From the results of data analysis that has been done by using computer assistance program SPSS for windows, it can be seen that the value of Fhitung is 6.254.

The Results of $\mathrm{F}_{\text {count }}$ and Discussion Because $F_{\text {count }}>F_{\text {table }}(6,254>0,004)$, then Ho is rejected, meaning operation variable, investment, and funding together have significant effect to Financial performance. The results of this $F$ test indicate that the model used is fit. Operating cash flow, investing and financing are used by the Officers' Boys' Training Unit to plan and manage all the needs of the Officers' LPKs to measure the advantages and disadvantages in achieving the Officer's Personnel's goal of earning measured profits using ROA.

\section{i. R2 Test}

Table 9. $\mathrm{R}_{2}$ Test Results

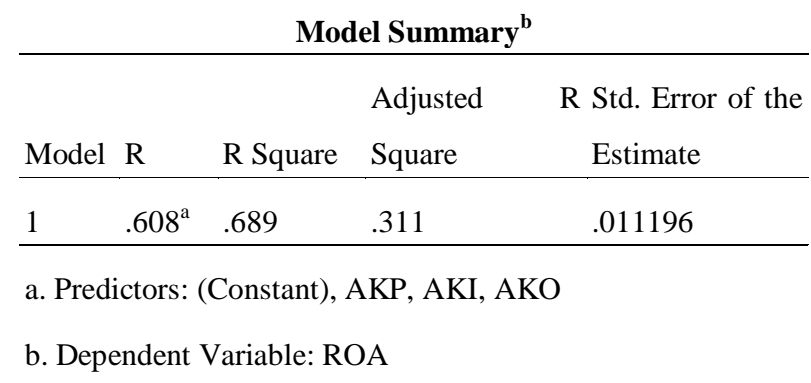

The calculation result for $\mathrm{R} 2$ value obtained in multiple regression analysis obtained coefficient of determination with adjustedR2 of 0.311 . This means that $31,10 \%$ variation of variable Financial performance can be explained by operation variable, investment, and funding while the rest that is $68,90 \%$ is explained by other factors outside the model under study. 
ISSN: 2454-1362, https://jurnal.stie-aas.ac.id/index.php/IJEBAR

\section{Conclusion}

a. Based on the results of the analysis and discussion then the conclusions that can be taken related to the influence of cash flow statements on financial performance. Operating cash flow variable has partially significant influence to financial performance. This is evidenced by the value of $t$ count $(0.176)$ is greater than ttable $(0.00075)$ or can be seen from the significance value of $0.045<\alpha=0.05$. Therefore, $\mathrm{H} 1$ is accepted.

b. Variable of investment cash flows have a significant influence on financial performance. It is proved by investment variable of tcount value $(0,103)$ bigger than ttabel $(0.00075)$ or can be seen from significance value $0,026<\alpha=0,05$. Therefore, $\mathrm{H} 2$ is accepted.

c. Variable cash flow of funding does not significantly influence partially to financial performance. It is proved by financing variable of tcount $(0,033)$ bigger than ttable $(0.00075)$ or can be seen from significance value $0,172>$ $\alpha=0,05$. Therefore, H3 is rejected.

d. Variable operating cash flows, investment cash flows and cash flow financing significantly affect the financial performance simultaneously. This is evidenced by the financing variable Fcount (6.254) is greater than Ftable (0.004). Therefore, H4 is accepted.

e. The influence of variable operating cash flows, investment cash flows and cash flow financing to financial performance seen from the value adjusted-R2 of 0.311 . This means that $31,10 \%$ variation of variable Financial performance can be explained by operation variable, investment, and funding while the rest that is $68,90 \%$ is explained by other factors outside the model under study.

\section{References}

Afrina, (2013). Analysis of Cash Flow Statements in Assessing Financial Performance at Village Unit Cooperative Sumber Makmur Kecamatan Kepenuhan. Arikunto, Suharsimi, (2002), Prosedur Penelitian Suatu Pendekatan Praktek, Jakarta. Rineka Cipta.

Darsono dan Ashari. (2005). Practical Guidelines Understanding Financial Statements. Andi: Yogyakarta. Fahmi Irham. (2013). Analisis Kinerja Keuangan, Bandung: Alfabeta.

Fahmi, I. (2006).Investment Analysis In Economic and Political Perspective. Bandung: Refika Aditama.

Ghozali, Imam. (2011). Application of Multivariate Analysis With IBM SPSS Program. Issue 5. Semarang: Diponegoro University Publishing Agency. Hanafi, Mamduh dan

Abdul Halim. (2005). Financial Statement Analysis. Second Edition. AMP-YKPN Publisher. Hanafi, Mamduh. (2007). Analisis Laporan Keuangan. Edisi Kedua. Penerbit AMP- YKPN.

Harahap, Sofyan S. (2008). Critical Analysis of Financial Statements, Issue One, Jakarta: PT. Raja Grafindo Persada.Harahap, S. (2013). Critical Analysis of Financial Statements. Jakarta: $\quad P T$ Raja Grafindo Persada.Hery Harjono Muljo. (2007). Teori Akuntansi. Jakarta: Salemba Empat.

Ikatan Akuntansi Indonesia. (2012). Statement of Financial Accounting Standards. Jakarta: Salemba Empat 
International Journal of Economics, Business and Accounting Research (IJEBAR)

Peer Reviewed - International Journal

Vol-2, Issue-1, 2018 (IJEBAR)

ISSN: 2454-1362, https://jurnal.stie-aas.ac.id/index.php/IJEBAR

Jumingan. (2006). Analisis Laporan Keuangan. Jakarta : Bumi Aksara.

Kieso, Donald E., Jerry J. Weygandt, dan Terry D. Warfield. (2002). Accounting Intermedite. Emil Salim's Translation, Tenth Edition, Volume Three, Jakarta : Erlangga.

Munawir. (2009). Management Accounting: Concepts of Benefits and Engineering. Yogyakarta: YKPN.

Masun, Mohammad. (2012). Public Sector Performance Measurement. Yogyakarta : BPFE.

Rando Riski Bawelle, (2015). Net Cash Flow Analysis Operation as a Financial Performance Measurement tool for cigarette industry in Indonesian securities.

Rakhman Syaeulholliq, (2007). Analisis Laporan Arus Kas untuk Menilai Kinerja Keuangan (survey pada perusahaan food and beverage yang terdaftar di BEJ ).

Sanusi, Anwar. (2012). Business Research Methodology. Third Print. Jakarta: Salemba Empat.

Silvia, (2015). The influence of cash flow on the financial performance of manufacturing companies listed on the BEI. Soemarsono, (2005). Akuntansi Suatu Pengantar. Edisi Lima. Jakarta: Salemba Empat.

Sucipto. (2013). Financial Performance Assessment. Jakarta: Ghalia

Wibowo dan Abubakar. (2003). Critical Analysis of Financial Statements. Issue One. Jakarta PT. Raja Grafindo Persada.. 